\title{
Gambaran Karakteristik Pengetahuan Ibu yang Memiliki Balita dengan ISPA di Puskesmas Siliwangi Garut
}

\author{
Sandra Pebrianti ${ }^{1}$, Iwan Shalahuddin ${ }^{2}$
}

\begin{abstract}
Abstrak
ISPA (Infeksi Saluran Pernafasan Atas) merupakan masalah kesehatan yang sering terjadi dimasyarakat khususnya pada bayi, balita dan anak-anak, ini merupakan cerminan bagi kita semua bahwa untuk mewujudkan tingkat derajat kesehatan yang tinggi tidaklah mudah.Infeksi saluran pernapasan akut. Pengetahuan adalah hasil dari tahu dan ini tejadi setelah seseorang melakukan suatu pengindraan terhadap suatu obyek tertentu. Pengindraan tejadi melalui panca indra manusia yaitu indra penglihatan, penciuman, rasa, raba, dan pengecapan. Sebagian besar pengetahuan manusia di peroleh melalui mata dan telinga. Tujuan Untuk mengetahui "Gambaran Pengetahuan Ibu yang Memiliki Balita tentang ISPA Berdasarkan Karakteristik di Puskesmas Siliwangi Garut. Sampel Populasi Sebanyak 20 responden dari yang berkunjung ke Puskesmas selama tiga hari. Hasil menunjukan bahwa umur responden yang memiliki pengetahuan baik adalah yang usia muda dengan rata rata tingkat pendidikan SLTA serta yang mendapatkan informasi dari media elektronik. Kesimpulannya adalah semakin muda usia dan semakin rajin mencari informasi dapat meningkatkan pengetahuan masyarakat.
\end{abstract}

Kata kunci : Balita, ISPA, Pengetahuan Ibu

\begin{abstract}
ISPA (Upper Respiratory Tract Infection) is a health problem that often occurs in the community especially in infants, toddlers and children, this is a reflection for all of us that to realize a high degree of health is not easy. Infection of the acute respiratory tract. Knowledge is the result of knowing and this happens after someone has sensed a certain object. Sensing occurs through the five human senses, namely the senses of sight, smell, taste, touch, and taste. Most human knowledge is obtained through the eyes and ears. Objective To find out "Overview of Knowledge of Mothers Who Have Toddlers about ISPA Based on the Characteristics at the Siliwangi Health Center in Garut. Sample Population A total of 20 respondents from those who visited the Puskesmas for three days. The results show that the age of respondents who have good knowledge is the young age with the average level of education in senior high school and those who get information from electronic media. The conclusion is that the younger the age and the more diligent search for information can increase public knowledge.
\end{abstract}

Keywords: ISPA Knowledge of Mother, Toddler,

\section{PENDAHULUAN}

Salah satu upaya untuk mencapai visi pembangunan kesehatan di indonesia, pemerintah membagi pelayanan kesehatan kepada masyarakat dengan membangun puskesmas yang merupakan suatu pelayanan kesehatan fungsional yang merupakan pusat pengembangan kesehatan masyarakat dengan memberikan pelayanan secara menyeluruh dan terpadu kepada masyarakat. Salah satu kegiatan pokok puskesmas adalah perawatan kesehatan masyarakat yang sasarannya adalah 
pembinaan terhadap keluarga rawan dimana keluarga tersebut beresiko terkena masalah kesehatan, maka akan timbul berbagai masalah kesehatan yang salah satunya adalah masalah tentang penyakit ISPA (Infeksi Saluran Pernapasan Akut).

ISPA merupakan masalah kesehatan yang sering terjadi di masyarakat khususnya pada bayi, balita dan anak-anak, ini merupakan cerminan bagi kita semua bahwa untuk mewujudkan tingkat derajat kesehatan yang tinggi tidaklah mudah. Infeksi saluran pernapasan akut (ISPA) merupakan salah satu dari berbagai penyakit penyebab kematian yang paling banyak pada anak-anak dan balita di Negara berkembang. ISPA adalah suatu kelompok penyakit sebagai penyebab angka absensi tertinggi dibandingkan dengan kelompok penyakit lain. Lebih $50 \%$ dari absensi atau dari semua angka tidak masuk kerja atau sekolah disebabkan penyakit ini. Di Negara barat, kasus ini banyak dijumpai pada musim dingin, awal musim gugur, atau pada masa-masa pergantian musim (Hood Alsegaff, 2010).

Menurut WHO, 2003 bahwa penyakit Infeksi Saluran Pernapasan Akut ini menyebabkan 4 dari 15 juta perkiraan kematian pada anak berusia dibawah 5 tahun dan pada setiap tahunnya sebanyak dua pertiga kematian tersebut adalah bayi. Salah satu yang termasuk dalam daftar penyakit Infeksi Saluran Pernapasan Akut adalah batuk, pilek, sakit telinga, radang tenggorokan, influenza, bronchitis, sinusitis dll. Sedangkan infeksi yang menyerang saluran pernapasan bagian bawah yang paling berbahaya yaitu Pneumonia. Di Indonesia sendiri ISPA merupakan penyebab utama masalah kesehatan morbiditas dan mortalitas pada golongan usia balita. ISPA juga merupakan urutan pertama penyebab kematian bayi dan balita. Hasil Survey mortalitas yang dilakukan oleh Subdit menempatkan ISPA (Pneumonia) sebagai penyebab kematian, presentasi 22,30\% dari seluruh balita.

Ini merupakan permasalahan kesehatan yang harus segera ditanggulangi karena balita rentan terserang bakteri, virus maupun jasad renik dan penyakit saluran pernapasan pada balita dikhawatirkan akan menjadi kecacatan sampai pada pada masa dewasa. Meningkatnya angka kesakitan penyakit ISPA di Kabupaten Garut dari tahun ke tahun semakin tinggi, salah satunya ditentukan tingkat pengetahuan, karena pengetahuan menentukan sikap seseorang berprilaku sehat.

Pengetahuan adalah hasil dari tahu dan ini tejadi setelah seseorang melakukan suatu pengindraan terhadap suatu obyek tertentu. Pengindraan tejadi melalui panca indra manusia yaitu indra penglihatan, penciuman, rasa, raba, dan pengecapan. Sebagian besar pengetahuan manusia di peroleh melalui mata dan telinga. 
(Notoadmodjo, 2010). Pengetahuan tentang suatu obyek mengandung 2 aspek yaitu aspek positif dan aspek negatif. Kedua aspek inilah yang akan menentukan sikap sesorang terhadap obyek tertentu. Semakin banyak aspek positif dari obyek yang di ketahui maka menimbulkan sikap makin positif terhadap obyek tesebut (Notoadmodjo, 2010).

Berdasarkan Data Profil Puskesmas Siliwangi Garut, menunjukkan bahwa ISPA merupakan penyakit infeksi yang sering terjadi, penyakit ISPA menempati urutan pertama dari daftar 10 penyakit tertinggi di Puskesmas Siliwangi Garut ini. Jumlah pasien yang terkena ISPA khususnya pada Balita pada bulan Januari 2012 terdapat 618 pasien ,bulan Februari terdapat 970 pasien ,bulan Maret terdapat 990 pasien, bulan April terdapat 993 pasien, dan sampai bulan Mei terdapat 688 pasien berobat dengan penyakit ISPA.

Peran perawat sangatlah penting dalam mewujudkan derajat kesehatan masyarakat untuk memberantas penyakit menular baik yang bersifat promotif, preventif, kuratif dan rehabilitative di semua aspek lingkungan kegiatan pelayanan kesehatan.

\section{METODE PENELITIAN}

Desain penelitian yang digunakan adalah deskroptif dengan pendekatan cross sectional. Arikunto (2010) menyatakan bahwa penelitian deskriptif bertujuan untuk mengetahui gambaran Variabelvariabel dependen dan independent yang dilakukan secara bersamaan , pada penelitian ini tentang gambaran karakteristik pengetahuan ibu yang memiliki balita dengan ISPA di Puskesmas Siliwangi Garut. Rancangan cross sectional merupakan rancangan penelitian yang pengukuran atau pengamatanya dilakukan secara simultan pada satu saat atau sekali waktu (Hidayat, 2007).

Variabel dalam penelitian ini adalah gambaran karakteristik pengetahuan ibu yang memiliki balita dengan penyakit ISPA. Pengetahuan merupakan hasil dari apa yang diketahui seseorang dan ini terjadi setelah orang tersebut melakukan pengindraan terhadap objek tertentu. Pengetahuan atau kognitif merupakan dominant yang sangat penting untuk terbentuknya tindakan seseorang, sebagian pengetahuan manusia diperoleh melalui mata dan telinga (Notoatmodjo, 2010). Variabel penelitian terdiri dari variabel dependen dan independen. Variabel dependen adalah variabel yang variasinya dipengaruhi atau tergantung oleh satu atau lebih variabel bebas. Variabel dependen dalam penelitian ini adalah gambaran pengetahuan ibu yang memiliki balita tentang ISPA berdasarkan karakteristik. Sedangkan variabel independen dalam penelitian ini adalah variabel faktor yang 
mempengaruhi pengetahuan yaitu usia, pendidikan, dan media massa.

Populasi penelitian adalah seluruh subjek atau objek dengan karakteristik tertentu yang akan diteliti (Aziz Alimul, 2003). Populasi pada penelitian ini adalah seluruh ibu yang memiliki balita dengan penyakit ISPA yang berkunjung ke Puskesmas Siliwangi Garut selama tiga hari. Jadi jumlah populasi yang diteliti mencakup 20 orang.

Pengambilan sampel penelitian adalah sebagian dari jumlah dan karakteristik yang dimiliki oleh populasi tersebut (Setiadi, 2007). Dalam penelitian ini peneliti menggunakan teknik sampling jenuh yakni cara pengambilan sampel dengan mengambil anggota populasi semua menjadi sampel. Cara ini dilakukan karena populasinya kecil dan sampelnya kurang dari 30 orang. Sampel yang akan dijadikan responden dalam penelitian ini berjumlah 20 orang.

\section{HASIL DAN PEMBAHASAN}

\section{Hasil Penelitian}

Penelitian tentang Gambaran karakteristik pengetahuan ibu yang memiliki balita denga penyakit ISPA si Puskesmas Siliwangi Garut, dilakukan dengan mengobservasi dan mengisi angket yang telah ditentukan dengan hasil seperti yang dapat dilihat berikut ini :
Tabel 1. Distribusi Frekuensi Responden berdasarkan Pengetahuan Ibu yang Memiliki Balita dengan ISPA di Puskesmas Siliwangi Kabupaten Garut

\begin{tabular}{clcc}
\hline No & Kategori & Frekuensi & Persentase \\
\hline 1 & Baik & 1 & $5 \%$ \\
2 & Cukup & 11 & $55 \%$ \\
3 & Kurang & 8 & $40 \%$ \\
\hline & Total & $\mathbf{2 0}$ & $\mathbf{1 0 0 \%}$
\end{tabular}

Berdasarkan tabel 1, menunjukan bahwa sebagian kecil pengetahuan responden tentang ISPA yaitu pengetahuan yang baik sebanyak 1 orang dengan presentase $5 \%$, lebih dari setengah berpengetahuan cukup sebanyak 11 orang dengan presentase $55 \%$ dan hampir setengahnya berpengetahuan kurang sebanyak 8 orang $(40 \%)$.

Tabel 2. Distribusi Frekuensi Responden Berdasarkan Umur Ibu yang Memiliki Balita dengan ISPA di Puskesmas Siliwangi Kabupaten Garut

\begin{tabular}{clcc}
\hline No & Umur & Frekuensi & Persen \\
\hline 1 & $21-30$ tahun & 10 & $50 \%$ \\
2 & $31-40$ tahun & 7 & $35 \%$ \\
3 & $41-50$ tahun & 3 & $15 \%$ \\
\hline & Total & $\mathbf{2 0}$ & $\mathbf{1 0 0 \%}$ \\
\hline
\end{tabular}

Berdasarkan tabel 2, menunjukan bahwa responden dengan usia antara 21-30 tahun setengahnya responden berjumlah 10 orang dengan persentase $50 \%$. Responden usia antara 21-30 tahun hampir setengahnya berjumlah 7 orang dengan persentase $35 \%$, responden 41-50 tahun sebagian kecil berjumlah 3 orang dengan persentase $15 \%$. 
Tabel 3. Distribusi Fekuensi Responden Berdasarkan Pendidikan Ibu yang Memiliki Balita dengan ISPA di Puskesmas Siliwangi Kabupaten Garut

\begin{tabular}{clcc}
\hline No & Pendidikan & Frekuensi & Persen \\
\hline 1 & SD, SMP & 6 & $30 \%$ \\
2 & SMK, SMU & 12 & $60 \%$ \\
3 & D3, S1 ,S2 dst & 2 & $10 \%$ \\
\hline & Total & $\mathbf{2 0}$ & $\mathbf{1 0 0} \%$ \\
\hline
\end{tabular}

Berdasarkan tabel 3, menunjukan bahwa responden berpendidikan SD, SMP hampir setengahnya berjumlah 6 orang dengan persentase $30 \%$, responden berpendidikan SMK, SMU lebih dari setengah berjumlah 12 orang dengan persentase $60 \%$ dan responden berpendidikan D3, S1, S2 sebagian kecil berjumlah 2 orang dengan presentase 10 $\%$.

Tabel 4. Distribusi Fekuensi Responden Berdasarkan Sumber Pengetahuan Ibu dari Media di Puskesmas Siliwangi Kabupaten Garut

\begin{tabular}{llcc}
\hline \multirow{2}{*}{ No } & \multicolumn{1}{c}{ Media massa } & $\begin{array}{c}\text { Frekuens } \\
\text { i }\end{array}$ & Persen \\
\hline 1 & Media cetak & 4 & $20 \%$ \\
2 & Media Elektronik & 8 & $40 \%$ \\
3 & $\begin{array}{l}\text { Petugas kesehatan } \\
4\end{array}$ & 2 & $10 \%$ \\
& $\begin{array}{l}\text { Responden yang Belum pernah } \\
\text { mendapatkan informasi tentang ISPA }\end{array}$ & 6 & $30 \%$ \\
\hline & Total & $\mathbf{2 0}$ & $\mathbf{1 0 0} \%$ \\
\hline
\end{tabular}

Berdasarkan tabel 4, menunjukan bahwa responden mendapatkan informasi tentang ISPA dari Media cetak sebagian kecil berjumlah 4 orang dengan presentase 20\%, dari media elektronik hampir setengahnya berjumlah 8 orang dengan persentase $40 \%$, dan dari petugas kesehatan sebagian kecil berjumlah 2 orang dengan presentase $10 \%$, sedangkan responden yang belum pernah mendapatkan informasi tentang ISPA hampir setengahnya berjumlah 6 orang dengan presentase $30 \%$.

Tabel 5. Gambaran Pengetahuan Responden Berdasarkan Karakteristik Umur Ibu yang Memiliki Balita dengan ISPA di Puskesmas Siliwangi Kabupaten Garut

\begin{tabular}{clccccccc}
\hline & & \multicolumn{6}{c}{ Pengetahuan } & \multirow{2}{*}{ Numlah } \\
\cline { 2 - 7 } No & Umur & \multicolumn{2}{c}{ Baik } & \multicolumn{2}{c}{ Cukup } & \multicolumn{2}{c}{ Kurang } & \\
\cline { 2 - 7 } & & F & $\mathbf{\%}$ & $\mathbf{F}$ & $\mathbf{\%}$ & $\mathbf{F}$ & $\mathbf{\%}$ & \\
\hline 1 & $21-30$ thn & 1 & $10 \%$ & 3 & $30 \%$ & 6 & $60 \%$ & 10 \\
2 & $31-40$ thn & - & $0 \%$ & 5 & $71,4 \%$ & 2 & $28,6 \%$ & 7 \\
3 & $41-50$ thn & - & $0 \%$ & 3 & $100 \%$ & - & $0 \%$ & 3 \\
& Jumlah & $\mathbf{1}$ & & $\mathbf{1 1}$ & & $\mathbf{8}$ & & $\mathbf{2 0}$ \\
\hline
\end{tabular}

Berdasarkan tabel 5, menunjukan bahwa responden dengan usia antara 21-30 tahun sebagian kecil berpengetahuan baik berjumlah 1 orang dengan persentase $10 \%$, 
hampir setengahnya responden berpengetahuan cukup berjumlah 3 orang dengan presentase $30 \%$, dan lebih dari setengah responden berpengetahuan kurang dengan jumlah 6 orang dengan presentase $60 \%$. Untuk usia 31-40 tahun tidak satupun responden berpengetahuan baik, lebih dari setengahnya responden berpengetahuan cukup berjumlah 5 orang dengan presentase $71,4 \%$, hampir setengah responden berpengetahuan kurang 2 orang dengan presentase $28,6 \%$, Untuk usia $41-$ 50 tahun tidak satupun berpengetahuan baik, seluruh responden berpengetahuan cukup berjumlah 3 orang dengan presentase $100 \%$

Tabel 6. Gambaran Pengetahuan Responden Berdasarkan Karakteristik Pendidikan Ibu yang Memiliki Balita dengan ISPA di Puskesmas Siliwangi Kabupaten Garut

\begin{tabular}{|c|c|c|c|c|c|c|c|c|}
\hline \multirow{3}{*}{ No } & \multirow{3}{*}{ Pendidikan } & \multicolumn{6}{|c|}{ Pengetahuan } & \multirow{3}{*}{ Jumlah } \\
\hline & & \multicolumn{2}{|c|}{ Baik } & \multicolumn{2}{|c|}{ Cukup } & \multicolumn{2}{|c|}{ Kurang } & \\
\hline & & $\mathbf{F}$ & $\%$ & $\mathbf{F}$ & $\%$ & $\mathbf{F}$ & $\%$ & \\
\hline 1 & SD, SMP & - & $0 \%$ & 3 & $50 \%$ & 3 & $50 \%$ & 6 \\
\hline 2 & SMK, SMU & 1 & $8,4 \%$ & 6 & $50 \%$ & 5 & $41,6 \%$ & 12 \\
\hline \multirow[t]{2}{*}{3} & D3,S1,S2 dst & - & $0 \%$ & 2 & $100 \%$ & - & $0 \%$ & 2 \\
\hline & Jumlah & 1 & & 11 & & 8 & & 20 \\
\hline
\end{tabular}

Berdasarkan tabel 6, menunjukan bahwa responden berpendidikan SD, SMP tidak satupun berpengetahuan baik, setengah dari responden berpengetahuan cukup berjumlah 3 orang dengan presentase 50\%, dan setengah dari responden memiliki pengetahuan kurang berjumlah 3 orang dengan presentase $50 \%$. Untuk responden berpendidikan SMK,SMU sebagian kecil berpengetahuan baik berjumlah 1 orang dengan presentase $8,4 \%$, setengahnya dari responden berpengetahuan cukup dengan jumlah 6 orang dengan presentase $50 \%$, dan hampir setengahnya berpengetahuan kurang berjumlah 5 orang presentase $41,6 \%$. Untuk responden berpendidikan D3, S1, S2 dst, responden seluruhnya berpengetahuan cukup dengan jumlah 2 orang dengan presentase $100 \%$.

Tabel 7. Gambaran Pengetahuan Responden Berdasarkan Karakteristik Media Massa pada Ibu yang Memiliki Balita dengan ISPA di Puskesmas Siliwangi Kabupaten Garut

\begin{tabular}{|c|c|c|c|c|c|c|c|c|}
\hline \multirow{3}{*}{ No } & \multirow{3}{*}{ Media Massa } & \multicolumn{6}{|c|}{ Pengetahuan } & \multirow{3}{*}{ Jumlah } \\
\hline & & \multicolumn{2}{|c|}{ Baik } & \multicolumn{2}{|c|}{ Cukup } & \multicolumn{2}{|c|}{ Kurang } & \\
\hline & & $\mathbf{F}$ & $\%$ & $\mathbf{F}$ & $\%$ & $\mathbf{F}$ & $\%$ & \\
\hline 2 & M.Elektronik & 1 & $12,5 \%$ & 4 & $50 \%$ & 3 & $37,5 \%$ & 8 \\
\hline 3 & P. kesehatan & - & $0 \%$ & 2 & $100 \%$ & - & $0 \%$ & 2 \\
\hline & Jumlah & 1 & & 11 & & 8 & & 20 \\
\hline
\end{tabular}


Berdasarkan tabel 7, menunjukan bahwa responden mendapatkan informasi dari media cetak tidak satupun berpengetahuan baik, lebih dari setengahnya responden berpengetahuan cukup berjumlah 3 orang dengan presentase $75 \%$ dan sebagian kecil responden berpengetahuan kurang berjumlah 1 orang dengan presentase $25 \%$. Untuk responden yang mendapatkan informasi dari media elektronik sebagian kecil responden berpengetahuan baik berjumlah 1 orang $(12,5 \%)$, setengahnya responden berpengetahuan cukup berjumlah 4 orang $(50 \%)$ dan hampir

\section{Pembahasan}

Hasil penelitian menunjukan bahwa pengetahuan responden tentang ISPA sudah cukup, pada tabel 5 menunjukan bahwa responden dengan usia 21-30 tahun sebagian kecil berpengetahuan baik 1 orang dengan persentase 10\%, hampir setengah responden berpengetahuan cukup berjumlah 3 orang dengan presentase $30 \%$, dan lebih dari setengah responden berpengetahuan kurang dengan jumlah 6 orang dengan presentase $60 \%$. Untuk usia 31-40 tahun tidak satupun responden berpengetahuan baik, lebih dari setengah responden berpengetahuan cukup 5 orang presentase $71,4 \%$, dan hampir setengahnya responden berpengetahuan kurang 2 orang dengan presentase $28,6 \%$, setengahnya responden berpengetahuan kurang berjumlah 3 orang $(37,5 \%)$. Untuk responden yang mendapat informasi dari petugas kesehatan, tidak satupun memiliki pengetahuan baik, seluruh responden berpengetahuan cukup 2 orang (100\%) dan tidak satupun responden berpengetahuan kurang. Bagi responden yang belum pernah mendapat informasi ISPA, tidak satupun responden berpengetahuan baik, hampir setengah responden memiliki pengetahuan cukup $(33,3 \%)$, dan lebih dari setengah responden pengetahuan kurang berjumlah 4 orang $(66,7 \%)$.

Untuk usia 41-50 tahun tidak satupun berpengetahuan baik, seluruh responden berpengetahuan cukup berjumlah 3 orang dengan presentase $100 \%$, ini menunjukkan bahwa dengan pengetahuan cukup saja tidak dapat mengatasi permasalahan penyakit ISPA, dengan umur masih muda lebih cepat mendapat informasi dibanding umur yang lebih tua lebih lambat untuk menerima informasi karena umur merupakan proses penuaan alamiah (Maramis, Ismanto \& Babakal, A, 2013).

Pengetahuan merupakan hasil tahu dan ini terjadi melalui panca indra manusia (Efendi, 2009). Pengetahuan seseorang tentang suatu objek mengandung dua aspek yaitu aspek positif dan aspek negatif, pernyataan ini didukung penelitian bahwa ada hubungan yang signifikan antara 
tingkat pengetahuan ibu dengan upaya perawatan terhadap balita ISPA (Andriani, \& Defita, 2015). Tingkat pengetahuan seseorang yang semakin tinggi akan berdampak pada arah yang lebih baik, sehingga ibu yang berpengetahuan yang baik akan lebih objektif dan terbuka wawasannya dalam mengambil keputusan atau tindakan positif (Ristiyanto, R, 2015). Upaya untuk meningkatkan pengetahuan khusus nya kepada umur 41-50 thn yaitu dengan diberikan pengetahuan kembali tentang pengertian, tanda gejala, penyebab, klasifikasi, perawatan, pencegahan, penularan, penyebaran dari ISPA, supaya mereview kembali pengetahuan yang dimiliki oleh responden.

Responden dengan pendidikan SD, SMP tidak satupun berpengetahuan baik, setengah dari responden berpengetahuan cukup berjumlah 3 orang presentase $50 \%$, dan setengah responden berpengetahuan kurang berjumlah 3 orang presentase $50 \%$. Untuk responden berpendidikan SMK, SMU sebagian kecil berpengetahuan baik dengan jumlah 1 orang presentase $8,4 \%$, setengah dari responden berpengetahuan cukup jumlah 6 orang dengan presentase $50 \%$, dan hampir setengahnya berpengetahuan kurang dengan jumlah 5 orang dengan presentase $41,6 \%$.

Untuk responden berpendidikan D3, S1, S2 dst, responden seluruhnya berpengetahuan cukup dengan jumlah 2 orang presentase $100 \%$, ini menunjukkan bahwa semakin tinggi tingkat pendidikan responden semakin mudah menerima informasi, dan semakin rendah tingkat pendidikan responden semakin lambat mendapatkan informasi karena dengan tingkat pendidikan yang berbeda akan mempengaruhi sikap dan prilaku sehat.

Pengetahuan tentang ISPA.

Pendidikan orang tua berpengaruh terhadap insidensi ISPA pada anak. Semakin rendah pendidikan orangtua derajat ISPA yang diderita anak semakin berat. Demikian sebaliknya, semakin tinggi pendidikan orang tua, derajat ISPA yang diderita anak semakin ringan (Ayu, S. D, 2008). ISPA cenderung lebih tinggi pada kelompok dengan pendidikan dan tingkat pengeluaran per kapita lebih rendah (KemenKes, R. I, 2007). Upaya untuk meningkatkan pengetahuan khusus nya kepada responden yang berpendidikan SD,SMP yaitu memperbaiki pengetahuan yang dimiliki oleh pertugas kesehatan sendiri, baiknya memberikan penyuluhan sampai responden benar-benar memahami apa yang disampaikan oleh petugas kesehatan tentang informasi ISPA.

Untuk responden dengan mendapatkan informasi dari media cetak tidak satupun berpengetahuan baik, lebih dari setengah responden berpengetahuan cukup berjumlah 3 orang dengan presentase $75 \%$ dan sebagian kecil 
responden berpengetahuan kurang berjumlah 1 orang dengan presentase $25 \%$. Untuk responden yang mendapatkan informasi dari media elektronik sebagian kecil responden berpengetahuan baik berjumlah 1 orang presentase $12,5 \%$, setengahnya responden berpengetahuan cukup berjumlah 4 orang presentase $50 \%$ dan hampir setengahnya responden berpengetahuan kurang berjumlah 3 orang dengan presentase $37,5 \%$.

Untuk responden yang mendapatkan informasi dari petugas kesehatan, tidak satupun responden berpengetahuan baik, seluruhnya responden berpengetahuan cukup berjumlah 2 orang presentase $100 \%$ dan tidak satupun responden berpengetahuan kurang. Bagi responden yang belum pernah mendapatkan informasi tentang ISPA, tidak satupun responden berpengetahuan baik, hampir setengahnya responden berpengetahuan cukup 2 orang dengan presentase $33,3 \%$, dan lebih dari setengahnya responden berpengetahuan kurang berjumlah 4 orang dengan presentase $66,7 \%$. Hal ini menunjukkan bahwa semakin rajin responden mencari informasi dari media massa semakin cepat mendapat informasi sedangkan semakin malas responden mencari informasi akan semakin kurang informasi yang didapatkan karena dengan mengakses informasi dengan banyaknya teknologi dapat mempengaruhi tingkat pengetahuan responden (Maulana \& Kes, M, 2009).

Pengetahuan tentang ISPA itu penting untuk mengurangi angka kejadian ISPA peneliti yang dilakukan oleh (Aderita, N, I, 2012) bahwa data yang diperoleh mengenai pengetahuan ibu tentang ISPA, dari hasil survey terhadap 10 orang ibu yang anaknya menderita ISPA, 7 diantaranya tidak mengetahui tentang penyakit ISPA dan 3 sisanya mengetahui tentang ISPA. Dari survey yang sama dilakukan pada 10 orang ibu, 5 orang ibu mengatakan anaknya menderita ISPA karena tertular dari keluarga lain, $3 \mathrm{ibu}$ berikut mengatakan anaknya ISPA karena minum es, kemudian 2 ibu sisanya mengatakan anaknya tiba-tiba sakit.

Upaya yang dapat dilakukan untuk meningkatkan pengetahuan responden itu sendiri yaitu responden harus lebih aktif mencari sumber informasi tentang ISPA baik dari media cetak, media elektronik, ataupun dari petugas kesehatan sendiri agar dapat memberikan informasi dan lebih berinteraktif, memberikan penyuluhan atau pemberian leaflet, brosur, poster kesehatan mengenai ISPA agar responden dapat memahami dan mengingatnya (Utari, W., \& Novayelinda, R, 2013).

\section{KESIMPULAN DAN SARAN}

\section{Kesimpulan}

Gambaran pengetahuan ibu berdasar karakteristik umur 21-30 tahun yaitu 
meiliki pengetahuan baik 10\%, ini menunjukkan bahwa dengan umur masih muda lebih cepat mendapatkan informasi dibandingkan umur yang lebih tua lebih lambat untuk menerima informasi karena umur merupakan proses penuaan yang alamiah.

Pengetahuan berdasar karakteristik pendidikan responden bahwa SMK,SMU menunjukan baik, ini menunjukkan bahwa semakin tinggi tingkat pendidikan responden semakin mudah menerima informasi, dan semakin rendah tingkat pendidikan responden semakin lambat mendapatkan informasi.

Pengetahuan berdasar karakteristik media massa, untuk responden yang menerima informasi dari media elektronik menunjukan pengetahuan yang baik, ini menunjukkan bahwa semakin rajin responden mencari informasi dari media massa semakin cepat mendapatkan informasi sedangkan semakin malas responden mencari informasi akan semakin kurang informasi yang didapatkan karena dengan mengakses informasi dengan banyaknya teknologi dapat mempengaruhi tingkat pengetahuan. Secara umum pengetahuan responden mengenai ISPA berada dalam tingkat pengetahuan cukup.

\section{Saran}

Diharap untuk kelompok respoden berumur 41-50 tahun, yaitu diberikan pengetahuan kembali tentang pengertian, tanda gejala, penyebab, klasifikasi, perawatan, pencegahan, penularan, penyebaran dari ISPA, supaya mereview kembali pengetahuan yang dimiliki oleh responden. Untuk kelompok responden berpendidikan SD,SMP yaitu memperbaiki pengetahuan yang dimiliki oleh pertugas kesehatan sendiri, baiknya memberikan penyuluhan sampai responden benar-benar memahami apa yang disampaikan oleh petugas kesehatan tentang informasi ISPA. Untuk kelompok media massa yaitu dengan memberikan penyuluhan atau pemberian leaflet, brosur, poster kesehatan mengenai ISPA agar responden dapat memahami dan mengingatnya.

1, 2 Fakultas Keperawatan Universitas Padjadjaran

\section{DAFTAR PUSTAKA}

Aderita, N. I. (2012). Hubungan antara tingkat pengetahuan dan sikap ibu dalam pencegahan ISPA dengan kejadian ISPA pada anak balita di desa pucangan wilayah kerja puskesmas kartasura I.

Alimul, A. (2003). Riset keperawatan dan teknik penulisan ilmiah. Jakarta: Salemba Medika.

Andriani, M., \& Defita, A. P. (2015). Hubungan Pengetahuan Dan Sikap Ibuterhadap Kejadian ISPA Pada Balita Di Wilayah Kerja Puskesmas Tigo Baleh Bukittinggi Tahun 2014. 'AFIYAH, 2(1).

Arikunto, Suharsimi. (2010). Prosedur Penelitian Suatu Pendekatan Praktik. Edisi Revisi. Jakarta: PT Rineka Cipta.

Ayu, S. D. (2008). Pengaruh Program Pendampingan Gizi Terhadap Pola Asuh, Kejadian Infeksi Dan Status Gizi Balita Kurang Energi Protein 
The Effect Of Nutritional Outreach Program On Caring Pattern, Infectious Disease Rates And The Anthropometric Status of Underweight Underfive Children (Doctoral dissertation, Program Pasca Sarjana Universitas Diponegoro).

Ferry Efendi, M. (2009). Keperawatan Kesehatan Komunitas: teori dan praktik dalam keperawatan. Ferry Efendi.

Hidayat. (2007). Pengantar Konsep Dasar Keperawatan. Jakarta: Salemba medika.

KemenKes, R. I. (2007). Riset kesehatan dasar (Riskesdas). Jakarta: Badan Litbangkes DepKes RI. Tersedia di https://www. k4health. org/sites/defa ult/files/laporanNasional\% 20Riskes das,202007.

Maramis, P. A., Ismanto, A. Y., \& Babakal, A. (2013). Hubungan tingkat pendidikan dan pengetahuan ibu tentang ISPA dengan kemampuan ibu merawat balita ISPA pada balita di Puskesmas Bahu Kota Manado. Jurnal Keperawatan, 1(1).
Maulana, H. D., Sos, S., \& Kes, M. (2009). Promosi kesehatan. EGC.

Notoatmodjo, S. (2010). Pengetahuan Sikap dan Perilaku Manusia.

Notoatmodjo, Soekidjo. (2010). Metodologi Penelitian Kesehatan. Edisi Revisi Jakarta : PT Rineka Cipta.

Ristiyanto, R. (2015). Hubungan Antara Tingkat Pendidikan Formal Dan Pengetahuan Orang Tua Tentang Ispa Pada Balita Di Puskesmas Gatak (Doctoral dissertation, Univer sitas Muhammadiyah Surakarta).

Setiadi. (2007). Riset Keperawatan. Yogyakarta: Graha ilmu.

Utari, W., \& Novayelinda, R. (2013). Efektifitas pendidikan kesehatan terhadap peningkatan pengetahuan keluarga tentang Infeksi Saluran Pernapasan Akut (ISPA). Jurnal Online Mahasiswa Program Studi Ilmu Keperawatan Universitas Riau, 1(1), 1-7. 